\title{
PENGARUH MOTIVASI KERJA TERHADAP DISIPLIN PEGA WAI PADA BADAN PERENCANA PEMBANGUNAN DAERAH KABUPATEN TULANG BAWANG BARAT
}

\author{
Sidik Prayitno Isyadi ${ }^{(1)}$, Hazairin Habe ${ }^{(2)}$, Khairul Saleh ${ }^{(3)}$ \\ Fakultas Ekonomi Universitas Sang Bumi Ruwa Jurai \\ sidik.pisyadi@gmail.com,hazairin.habe@fe.saburai.ac.id, khairul.saleh@fe.saburai.ac.id
}

\begin{abstract}
Abstrak. Disiplin kerja sangat penting dimiliki oleh setiap pegawai yang bekerja, karena dengan disiplin maka pegawai tersebut bisa mengikuti peraturan yang sudah ditetapkan dengan baik. Dewasa banyak pegawai yang kehilangan semangat kerja sehingga menurunnya tingkat disiplin, oleh sebab itu perlu adanya suatu motivasi yang bisa mengembalikan rasa disiplin pegawai. Tujuan penelitian ini untuk mengetahui Pengaruh Disiplin Kerja dan Motivasi Kerja terhadap Kinerja Pegawai pada Badan Perencanaan Pembangunan Daerah Kabupaten Tulang Bawang Barat terhadap populasi sebagai responden sebanyak 47 orang. Metode pengumpulan data sebagai data primer melalui Observasi, Interview dan Kuesioner serta data skunder. Hasil Uji t untuk variabel Disiplin Kerja didapat nilai $t$ hitung $=3,260$ dan $t_{\text {hitung }}$ untuk variabel Motivasi Kerja $=0,869$. Apabila dibandingkan dengan $t_{\text {tabel }}$ pada taraf signifikan 0,05 yaitu 1,67, maka $t_{\text {hitung }}$ lebih besar dari tabel sehingga dapat disimpulkan bahwa Disiplin kerja (X) dan Motivasi Kerja (Y) berpengaruh terhadap variabel kinerja. Kemudian dalam persamaan : $Y=10,987+0,612 X$. Artinya setiap terjadi peningkatan nilai pada variabel Disiplin Kerja sebesar satu point, maka Kinerja akan meningkat sebesar 0,612 point dan setiap terjadi peningkatan nilai pada variabel Motivasi Kerja sebesar satu point, maka Kinerja akan meningkat sebesar 0,724 point.
\end{abstract}

Kata kunci: Disiplin, Kinerja, Motivasi, Pengaruh.

\section{PENDAHULUAN}

Disiplin kerja untuk memberikan pelayanan kepada masyarakat pada lembaga pemerintah dewasa ini atau pada lembaga apapun sedang hangat-hangatnya menjadi pembicaraan. Kedisiplinan menjadi ajang penilaian atasan atau lembaga terhadap karyawan atau pegawainya. Kedisiplinan merupakan salah satu kunci utama penyelenggaraan suatu lembaga terlebih lembaga pemerintahan, agar stigma yang selama ini muncul dimasyarakat dapat terjawab, bahwa saat kini para pegawai negeri khususnya telah dan mengutamakan kedisiplinan.

Karena ada suatu anggapan bahwa disiplin merupakan perasaan taat dan patuh terhadap pekerjaan yang menjadi tanggung jawab. Disiplin ini berhubungan erat dengan wewenang. Apabila wewenang tidak berjalan dengan semestinya, maka disiplin akan hilang. Oleh karena ini, pemegang wewenang harus dapat menanamkan disiplin terhadap dirinya sendiri sehingga mempunyai tanggung jawab terhadap pekerjaan sesuai dengan wewenang yang ada padanya.

Selain itu juga, kedisiplinan dapat menjadi bentuk tanggung jawab yang lambat laun menjadi tabiat. Kebiasaan yang baik akan menjadi budaya, sehingga oleh budaya akan mempengaruhi prilaku. Budaya menuntut individu untuk berperilaku dan memberi petunjuk pada para karyawan untuk mengenal apa saja yang harus diikuti dan dipelajari. Kondisi tersebut juga berlaku dalam suatu organisasi. Bagaimana karyawan berperilaku dan apa yang seharusnya mereka lakukan banyak dipengaruhi oleh budaya yang dianut oleh organisasi 
tersebut, atau diistilahkan sebagai budaya kerja.

Dengan budaya akan menggambarkan bahwa budaya kerja sesungguhnya tumbuh karena diciptakan dan dikembangkan oleh individu-individu yang bekerja dalam suatu organisasi, dan diterima sebagai nilai-nilai yang harus dipertahankan dan duturunkan kepada setiap anggota baru. Nilai-nilai tersebut digunakan sebagai pedoman bagi setiap anggota selama mereka berada dalam lingkungan organisasi tersebut dan dapat dianggap sebagai old khas (ke-khasan) yang membedakan sebuah organisasi dengan organisasi lainnya.

Suatu lembaga bukan hanya membutuhkan disiplin dari anggotanya, melainkan juga suatu sikap motivasi. Sebab apabila anggota suatu organisasi memiliki motivasi pada dirinya, maka tidak disanksikan lagi organisasi tersebut dapat berjalan dengan baik. Pengertian motivasi kerja menurut Siagian (2002), menyatakan bahwa yang diinginkan seseorang dari pekerjaannya pada umumnya adalah sesuatu yang mempunyai arti penting bagi dirinya sendiri dan bagi instansi. Sedangkan menurut Heidjachman dan Husnan (2003), motivasi merupakan proses untuk mencoba mempengaruhi seseorang agar melakukan sesuatu yang kita inginkan.

Sebagaimana terdapat dalam Struktur organisasi Bappeda Kabupaten Tulang Bawang Barat yang disusun berdasarkan Peraturan Daerah Kabupaten Tulang Bawang Barat Nomor 7 Tahun 2012 tentang Organisasi dan Tata Kerja Inspektorat, Badan Perencanaan Pembangunan Daerah, Badan Pelayanan Perizinan Terpadu, Badan Kepegawaian Daerah dan Lembaga Teknis Daerah yang dijabarkan dalam Peraturan Bupati Tulang Bawang Barat Nomor 59 Tahun 2012 tentang Uraian Tugas, Fungsi dan Tata Kerja Badan Perencanaan Pembangunan Daerah, telah ditegaskan bahwa kedudukan Bappeda sebagai unsur perencana penyelenggaraan pemerintahan daerah dan pelayanan kepada masyarakat sesuai dengan kebijakan Bupati. Badan Perencanaan Pembangunan Daerah melaksanakan Tugas pokok Penyusunan dan pelaksanaan Kebijakan daerah di bidang perencanaan pembangunan daerah.

Pemerintahan yang baik (good governance) merupakan isu yang paling mengemuka dalam pengelolaan administrasi publik dewasa ini. Tuntutan gencar yang dilakukan oleh masyarakat kepada pemerintah untuk penyelenggaraan pemerintahan yang baik adalah sejalan dengan meningkatnya tingkat pengetahuan masyarakat, disamping adanya globalisasi. Pola-pola lama dalam penyelenggaraan pemerintahan telah tidak sesuai lagi bagi tatanan masyarakat yang saat ini berubah. Oleh karenanya, tuntutan itu merupakan hal yang wajar dan telah seharusnya direspon oleh Pemerintah dengan melakukan perubahan yang terarah, pada terwujudnya penyelenggaraan pemerintahan yang baik.

Dengan berlakunya Undang-Undang Nomor 32 Tahun 2004 tentang Pemerintahan Daerah dan Undang-Undang Nomor 33 Tahun 2004 tentang Perimbangan Keuangan Antara Pusat dan Pemerintahan Daerah maka daerah mempunyai kewenangan yang lebih luas untuk mengatur rumah tangganya sendiri. Konsekuensi dari pelaksanaan UndangUndang tersebut adalah bahwa Pemerintah Daerah harus dapat lebih meningkatkan kinerjanya dalam penyelenggaraan pemerintahan, pembangunan, dan pelayanan kepada masyarakat.

Pelaksanaan penyelenggaraan pemerintahan yang baik tercermin dalam sistem akuntabilitas kinerja instansi pemerintah. Akuntabilitas merupakan perwujudan kewajiban instansi untuk mempertanggungjawabkan keberhasilan dan kegagalan pelaksanaan misi dalam mencapai tujuan dan sasaran yang telah ditetapkan melalui pertanggungjawaban 
yang dilaksanakan secara periodik (LAKIP).

Badan Perencanaan Pembangunan Daerah Kabupaten Tulang Bawang Barat sebagai salah satu instansi pemerintah daerah sesuai dengan bidang tugasnya membantu Kepala Daerah dalam penyelenggaraan pemerintah di bidang perencanaan pembangunan, berkewajiban juga menyusun rencana strategis. Dengan demikian diharapkan agar dapat menentukan arah perkembangan dalam meningkatkan kinerjanya, yang mampu menjawab tuntutan perkembangan lingkungan strategis baik lokal regional, nasional, maupun global.

Selain itu juga memberikan peringatan kepada bawahan terkait dengan pelanggaran disiplin sesuai dengan peraturan perundang-undangan masih terkesan subjektif dan kekeluargaan. Selain itu juga tentang Kedinasan, Rencana Kerja Anggaran, Perlengkapan Barang Dinas, Rancangan akhir LKPD, KUA / PPAS, Rancangan akhir RPJMD dan LPPD, Rancangan akhir LAKIP Dinas dan Rancangan akhir RKPD adalah elemen yang harus diketahui dan dikuasai oleh karyawan.

Namun terhadap hal tersebut, ada sebagain karyawan yang kurang memahami secara utuh tentang pelaporan pengelolaan keuangan dinas, rancangan hasil tindak lanjut tugas-tugas lain sehingga scara manajemen perlu adanya peningkatan motivasi dan prestasi kerja dengan tujuan meningkatnya disiplin kepegawaian. Kemudian masih ada beberapa karyawan yang bekerja tanpa prosedur kerja sekalipun telah tersedia SOP (Sistem Operasional Prosedur) terutama dalam pelayanan administrasi perkantoran.

Terhadap beberapa tugas yang wajib diketahui dan dikuasai oleh pegawai dilingkungan Bappeda Kabupaten Tulang Bawang Barat ternyata masih banyak pegawai yang belum atau masih terdapat sebagian pegawai yang belum mendapatkan Bimbingan Teknis (Bimtek) dan juga kurang mendapat Pembinaan, Pengawasan dan Pengendalian serta bimbingan atasan untuk meningkatkan motivasi kerja dan disiplin kerja. Kemudian atas dasar pengamatan, terlihat bahwa para pegawai Bappeda Kabupaten Tulang Bawang Barat masih rendah disiplinnya sehingga patut diduga penyebabnya adalah rendahnya manajemen sumber daya manusia dalam kedisiplinan yang belum berjalan secara efektif. Selain itu juga motivasi kerja pegawai dilingkungan Bappeda Kabupaten Tulang Bawang Barat belum tumbuh secara optimal.

Tingkat kehadiran karyawan Bappeda Kabupaten Tulang Bawang Barat dari 47 orang karyawan sebagian besar dalam satu bulannya terdapat karyawan yang tidak hadir. Pada bulan Januari 2016 terdapat ketidak hadiran karyawan sebanyak 5 orang karyawan dimana dari target $100 \%$ atau 47 orang karyawan maka realisasi masuknya karyawan pada bulan Januari adalah $6,4 \%$. Pada bulan April karyawan hanya ada 2 karyawan yang abstain atau realisasi dari kehadiran pada bulan April adalah 4,3\%. Selanjutnya terjadi ketidak hadiran atau abstain dari karyawan pada bulan Agustus sebanyak 16 orang karyawan atau realisasi dari kehadiran karyawan pada bulan Agustus adalah 34,04 \%. Kemudian pada bulan berikutnya yakni bulan September terjadi ketidak hadiran sebanyak 17 orang, sehingga pada bulan September terjadi realisasi dari ketidak hadiran karyawan adalah sebesar $36,17 \%$.

Namun demikian faktor ketidak disiplinan para karyawan dalam bentuk ketidakhadiran para karyawan selalu dilengkapi dengan surat keterangan sakit dari dokter dan yang untuk keperluan keluarga mereka melakukan penulisan surat keterangan tidak hadir. Adapun penyelenggaraan suatu proses kegiatan pelayanan pada masyarakat oleh Bappeda 
Kabupaten Tulang Bawang Barat merupakan kegiatan dalam berbagai urusan termasuk urusan wajib dan urusan pilihan. Berdasarkan beberapa faktor tersebut peneliti tertarik untuk meneliti dengan judul: "PENGARUH MOTIVASI KERJA TERHADAP DISIPLIN PEGAWAI PADA BADAN PERENCANA PEMBANGUNAN DAERAH KABUPATEN TULANG BAWANG BARAT".

\section{KAJIAN TEORI}

\section{Motivasi Kerja}

Sebagai landasan teori dalam penulisan ini, maka akan diketengahkan beberapa pengertian yang berhubungan. Pengertian motivasi menurut pendapat Hasibuan (2003), kata "motivasi" berasal dari bahasa latin "movere" yang berarti "dorongan atau daya penggerak". Dalam pemberian motivasi instansi mempunyai kesamaan tujuan, ada beberapa tujuan yang dapat diperoleh antara lain meningkatkan moral dan kepuasan kerja pegawai, meningkatkan prestasi kerja pegawai, menciptakan suasana dan hubungan kerja yang baik, meningkatkan loyalitas, kreatifitas dan partisipasi, meningkatkan tingkat kesejahteraan pegawai dan meningkatkan rasa tanggung jawab pegawai terhadap tugas.

Sedangkan Luthans (2006) menyebut elemen-elemen yang mempengaruhi motivasi adalah :

1. Motivasi motivational adalah hal-hal pendorong berprestasi yang sifatnya Intrinsik yang bersumber dari dalam diri seseorang. Yang tergolong faktor motivational adalah pekerjaan seseorang, keberhasilan yang diraih, kesempatan untuk berkembang, kemajuan dalam karir dan pengakuan orang lain.
2. Motivasi higiene atau pemeliharaan adalah faktor-faktor yang sifatnya ekstrinsik yang bersumber dari luar diri seseorang. Yang tergolong faktor higiene atau pemeliharaan antara lain status seseorang dalam organisasi, hubungan pegawai dengan atasan, hubungan dengan rekan kerja, kebijaksanaan organisasi, sistem administrasi dalam organisasi, kondisi kerja dan sistem imbalan yang berlaku.

Namun menurut Namawi (2003) membedakan motivasi ini dalam dua bentuk, yaitu motivasi instrinsik dan motivasi ekstrinsik.

1. Motivasi instrinsik adalah pendorong kerja yang bersumber dari dalam diri pekerja individu, berupa kesadaran mengenai pentingnya atau manfaat dan makna pekerjaan yang dilaksanakan. Dengan kata lain motivasi ini bersumber dari ketertarikan kepada pekerjaan, keinginan untuk berkembang, senang dan menikmati pekerjaan.

2. Motivasi ekstrinsik adalah pendorong kerja yang bersumber dari luar diri pekerja sebagai individu, berupa suatu kondisi yang mengharuskan melaksanakan pekerjaan secara maksimal. Misalanya berdedikasi tinggi dalam bekerja karena upah atau gaji yang tinggi, jabatan, penghargaan, persaingan dan menghindari hukuman dari atasan.

\section{Disiplin Kerja}

Arti dari disiplin menurut Hasibuan (2008), menyatakan bahwa kedisiplinan atau disiplin adalah kesadaran dan kesediaan seseorang mentaati semua peraturan dan norma-norma sosial yang berlaku. Dari pendapat diatas dapat disimpulkan bahwa disiplin kerja adalah suatu keadaan tertib dimana seseorang atau 
sekelompok yang tergabung dalam organisasi tersebut berkehendak mematuhi dan menjalankan peraturan yang ada, baik yang tertulis maupun tidak tertulis. Masih menurut Hasibuan (2008), menyatakan bahwa pada dasarnya banyak indikator yang mempengaruhi tingkat kedisiplinan pegawai diantaranya :

1. Tujuan dan kemampuan.

Tujuan dan kemampuan ikut mempengaruhi tingkat kedisiplinan pegawai. Tujuan yang dicapai harus jelas dan ditetapkan secara ideal serta cukup menantang bagi kemampuan pegawai. Hal ini berarti tujuan (pekerjaan) yang dibebankan kepada pegawai harus sesuai dengan kemampuan pegawai bersangkutan, agar dia bekerja sungguhsungguh dan disiplin dalam mengerjakannya.

2. Teladan pimpinan.

Teladan pimpinan sangat berperan dalam menentukan kedisiplinan pegawai karena pimpinan dijadikan teladan dan panutan oleh para bawahannya. Dengan teladan pimpinan yang baik, kedisiplinan bawahan pun akan ikut baik. Tetapi jika teladan pimpinan kurang baik (kurang disiplin), para bawahan pun pasti akan kurang disiplin.

3. Balas jasa.

Balas jasa ikut mempengaruhi kedisiplinan pegawai karena balas jasa akan memberikan kepuasan dan kecintaan pegawai terhadap pekerjaannya. Jika kecintaan pegawai semakin baik terhadap pekerjaan, kedisiplinan mereka akan semakin baik pula.

4. Keadilan.

Keadilan ikut mendorong terwujudnya kedisiplinan pegawai karena ego dan sifat manusia yang selalu merasa dirinya penting dan minta diperlakukan sama dengan manusia lainnya. Keadilan yang dijadikan dasar kebijakan dalam pemberian balas jasa (pengakuan) atau hukuman akan merangsang terciptanya kedisiplinan pegawai yang baik.

5. Waskat.

Waskat (pengawas melekat) adalah tindakan nyata dan paling efektif dalam mewujudkan kedisiplinan pegawai. Dengan waksat berarti atasan harus aktif dan langsung mengawasi perilaku, moral, sikap, gairah kerja dan prestasi kerja bawahannya. Waskat efektif merangsang kedisiplinan dan moral kerja pegawai. Pegawai merasa mendapat perhatian, bimbingan, petunjuk, pengarahan dan pengawasan dari atasan.

6. Sanksi hukum.

Sanksi hukuman berperan penting dalam memelihara kedisiplinan pegawai. Dengan sanksi hukuman yang semakin berat, pegawai akan semakin takut melanggar peraturan-peraturan, sikap dan perilaku indisipliner pegawai akan berkurang. Berat atau ringannya sanksi hukuman yang akan diterapkan ikut mempengaruhi baik atau buruknya kedisiplinan pegawai.

7. Ketegasan.

Ketegasan pimpinan menegur dan menghukum setiap pegawai yang indisipliner akan mewujudkan kedisiplinan yang baik pada suatu instansi.

8. Hubungan kemanusiaan.

Pimpinan harus berusaha menciptakan suasana hubungan kemanusiaan yang serasi serta mengikat semua pegawainya. Terciptanya human relationship yang serasi akan mewujudkan lingkungan dan suasana kerja yang nyaman. Hal ini jelas akan memotivasi kedisiplinan yang baik pada suatu instansi. 


\section{Human Capital dan Produktivitas}

Hakekatnya dalam suatu lembaga, setiap pekerjaan akan diikuti oleh manusia yang berperan didalamnya. Karena hanya manusialah yang dapat mengerjakan suatu pekerjaan. Oleh sebab itu dirasa sangat peing apa bila dalam penulisan ini meninjau peran sumber daya manusia.

Secara teoritis, pembangunan mensyaratkan adanya sumber daya manusia (SDM) yang berkualitas, sehingga dapat meningkatkan produktivitas kerja. Unutuk mencapai SDM yang berkualitas dibutuhkan pembentukan modal manusia (human capital).

Menurut (Davenport), human capital merupakan seluruh usaha yang dibawa tenaga kerja untuk diinvestasikan dalam pekerjaan mereka. Termasuk juga di dalamnya kemampuan, tingkah laku, semangat dan waktu. Pembentukan modal manusia ini merupakan suatu bentuk untuk memperoleh sejumlah manusia yang memiliki karakter kuat yang dapat digunakan sebagai modal penting dalam pembangunan. Menurut (Davenport), human capital merupakan seluruh usaha yang dibawa tenaga kerja untuk diinvestasikan dalam pekerjaan mereka. Termasuk juga di dalamnya kemampuan, tingkah laku, semangat dan waktu.

Pengertian produktivitas dapat dilihat dari dua dimensi yaitu dimensi individu dan dimensi keorganisasian. Dimensi individu melihat produktivitas dalam kaitannya dengan karakteristik-karakteristik kepribadian individu yang muncul dalam bentuk sikap mental dan mengandung makna keinginan dan upaya individu yang selalu berusaha untuk meningkatkan kualitas kehidupannya. Sedangkan dimensi keorganisasian melihat produktivitas dalam kerangka hubungan teknis antara masukan (input) dan keluaran (output). Tingkat produktivitas dapat diukur dengan menggunakan :
1. Penggunaan waktu.

Didalam penggunaan waktu kerja, yang digunakan tenaga kerja untuk menghasilkan output dan sebagai alat ukur produktivitas kerja meliputi kecepatan waktu kerja, penghematan waktu kerja, kedisiplinan waktu kerja, dan tingkat absensi.

2. Output yang dihasilkan.

Banyaknya output yang dihasilkan oleh tenaga kerja juga digunakan sebagai alat ukur produktivitas kerja di mana semakin banyak output yang dihasilkan pekerja maka produktivitas kerja dan tenaga kerja akan semakin baik. Banyaknya output yang dihasilkanpun harus diikuti dengan kualitas pekerjaan yang dilakukan. Pengukuran produktivitas kerja inilah yang digunakan sebagai sarana untuk menganalisa dan mengukur efisiensi suatu kinerja.

\section{METODE PENELITIAN}

\section{Objek Penelitian}

Objek penelitian ini adalah para pegawai Badan Perencanaan Pembangunan Daerah Kabupaten Tulang Bawang Barat Jalan Jend. Soedirman Komplek Pemerintah Daerah Kabupaten Tulang Bawang Barat Kecamatan Tulang Bawang Tengah yang berlangsung pada bulan April hingga Juni 2016.

\section{Metode dan Teknik Pengumpulan Data}

Penelitian ini menggunakan jenis penelitian kuantitatif dengan pendekatan survey metode eksplanatif yaitu suatu metode pemberian penjelasan untuk melihat kaitan antar variabel dan selanjutnya mengambil langkah berupa penjelasanpenjelasan yang mengkaitkan antar variabel tersebut. 
Dalam penelitian ini jenis data yang diperlakukan adalah :

\section{a. Data Primer}

Data primer merupakan data dasar yang akan diperoleh langsung tanpa perantara orang atau lembaga lain sebagai pihak ketiga. Data primer ini diperoleh dengan wawancara melalui responden dengan menggunakan daftar pertanyaan.

b. Data Sekunder

Data skunder merupakan data yang diperoleh melalui orang lain yang berhubungan dengan permasalahan yang dipecahkan. Data sekunder ini diperoleh melalui cara studi dokumenter yaitu mengumpulkan dan mempelajari brosurbrosur serta dokumen organisasi.

\section{Sampel dan Populasi}

Menurut Nanang Martono (2011) mendifinisikan populasi adalah seluruh objek atau subjek yang berada pada suatu wilayah dan memenuhi syarat-syarat tertentu berkaitan dengan masalah penelitian, atau keseluruhan unit atau individu dalam ruang lingkup yang akan diteliti. Pada penelitian ini seluruh Pegawai dijadikan responden. Berdasarkan data yang ada jumlah pegawai adalah 47 orang, kemudian menurut S. Arikunto (2007) apabila objek penelitian kurang dari 100 maka lebih baik diambil semua. Menurut data yang ada jumlah populasi dalam penelitian ini berjumlah kurang 100 sehingga penulis mengambil semua populasi yaitu 47 orang.

\section{Metode Analisis Data}

Untuk pengolahan data dalam bentuk tabulasi hasil jawaban responden kemudian dilakukan analisis data melalui metode analisis secara kualitatif dan analisis kuantitatif.
Analisis kualitatif merupakan langkah penganalisaan yang diarahkan untuk menganalisis permasalahan yang ada dengan cara mengkaji teori yang berkaitan dengan pengukuran Motivasi dan Kedisiplinan kerja pegawai Badan Perencanaan Pembangunan Daerah Kabupaten Tulang Bawang Barat.

Untuk mengetahui Pengaruh Motivasi dan Disiplin kerja Pegawai pada Badan Perencanaan Pembangunan Daerah Kabupaten Tulang Bawang Barat, maka analisis yang digunakan menggunakan rumus statistis Regresi Linear Sederhana, yaitu :

$$
Y=a+b X+e
$$

Keterangan:

$$
\begin{aligned}
& \mathrm{Y}=\text { Disiplin Pegawai } \\
& \mathrm{a}=\text { Konstanta } \\
& \mathrm{b}=\text { Koefisien regresi } \mathrm{X} \\
& \mathrm{X}=\text { Motivasi kerja } \\
& \mathrm{e}=\text { Faktor kesalahan }
\end{aligned}
$$

Untuk mengetahui besarnya pengaruh, penghitungan koefisien korelasi tersebut kemudian dilanjutkan dengan Rumus Koefisien Determinasi atau Koefisien Penentu (KP):

$$
K P=(r)^{2} x 100 \%
$$

Untuk menguji secara hipotesis secara parsial digunakan Uji t dengan rumus :

$$
t_{\text {hitung }}=\frac{r \sqrt{N-2}}{\sqrt{1-r^{2}}}
$$

Keterangan:

$$
\begin{array}{ll}
\mathrm{t}_{\text {hitung }} & =\text { Nilai } \mathrm{t} \\
\mathrm{r} & =\text { Koefisien Korelasi } \\
\mathrm{N} & =\text { Jumlah responden }
\end{array}
$$

Kriteria untuk Uji $t$ adalah sebagai berikut : 
a) Jika $t_{\text {hitung }}>t_{\text {tabel }}$ maka Ha diterima dan Ho ditolak.

b) Jika $t_{\text {hitung }} \leq \mathrm{t}_{\text {tabel }}$ maka Ha ditolak dan Ho diterima.

Taraf signifikan dalam penelitian ini digunakan $\alpha=0,05$ atau 5\%. Yang dimaksud dengan Hipotesis nol (Ho) dan Hipotesis alternatif (Ha) adalah :

Ho $=r \leq 0=$ Berarti tidak ada pengaruh motivasi kerja terhadap disiplin pegawai $\mathrm{Ha}=\mathrm{r}>0=$ Berarti ada pengaruh motivasi kerja terhadap disiplin pegawai.

\section{HASIL DAN PEMBAHASAN}

\section{Analisis Kualitatif Uji Validitas Instrumen}

Uji validitas digunakan untuk menguji sejauh mana ketepatan alat pengukur dapat mengungkapkan konsep gejala/ kejadian yang diukur. Item kuesioner dinyatakan valid apabila nilai $r$ hitung $>r$ tabel $(n-2)$. Pengujian validitas selengkapnya dapat dilihat pada tabel berikut ini:

Tabel 1. Hasil Pengujian Validitas

\begin{tabular}{|c|c|c|c|c|}
\hline NO & Variabel/Indikator & $\mathrm{r}_{\text {hitung }}$ & $\mathrm{r}_{\text {table }}$ & Keterangan \\
\hline \multirow[t]{11}{*}{1} & Motivasi Kerja & & & \\
\hline & X.1 & 0.7743 & 0,297 & Valid \\
\hline & X.2 & 0.7544 & 0,297 & Valid \\
\hline & X.3 & 0.7551 & 0,297 & Valid \\
\hline & X.4 & 0.6662 & 0,297 & Valid \\
\hline & X.5 & 0.7681 & 0,297 & Valid \\
\hline & X.6 & 0.5584 & 0,297 & Valid \\
\hline & $X .7$ & 0.6594 & 0,297 & Valid \\
\hline & X.8 & 0.6576 & 0,297 & Valid \\
\hline & X.9 & 0.7596 & 0,297 & Valid \\
\hline & X.10 & 0.8566 & 0,297 & Valid \\
\hline \multirow[t]{11}{*}{3} & Disiplin Pegawai & & & \\
\hline & Y.1 & 0.6569 & 0,297 & Valid \\
\hline & Y.2 & 0.7784 & 0,297 & Valid \\
\hline & Y.3 & 0.7760 & 0,297 & Valid \\
\hline & Y.4 & 0.6709 & 0,297 & Valid \\
\hline & Y.5 & 0.6701 & 0,297 & Valid \\
\hline & Y.6 & 0.7522 & 0,297 & Valid \\
\hline & Y.7 & 0.6434 & 0,297 & Valid \\
\hline & Y.8 & 0.6723 & 0,297 & Valid \\
\hline & Y.9 & 0.6922 & 0,297 & Valid \\
\hline & Y.10 & 0.8601 & 0,297 & Valid \\
\hline
\end{tabular}

Dari Tabel 1. terlihat bahwa korelasi antara masing-masing indikator terhadap total skor konstruk dari setiap variabel menunjukkan hasil yang signifikan, dan menunjukkan bahwa $\mathrm{r}$ hitung $>\mathrm{r}$ tabel. Sehingga dapat disimpulkan bahwa semua item pertanyaan dinyatakan valid.

\section{Uji Reliabilitas Instrumen}

Uji reliabilitas digunakan untuk menguji sejauh mana keandalan suatu alat pengukur untuk dapat digunakan lagi untuk penelitian yang sama. Pengujian reliabilitas dalam penelitian ini adalah dengan menggunakan rumus Alpha. Hasil uji reliabilitas tersebut telah menunjukkan bahwa semua variabel mempunyai nilai koefisien Alpha yang cukup besar yaitu diatas 0,879 sehingga dapat dikatakan semua konsep pengukur masing-masing variabel dari kuesioner adalah reliabel sehingga untuk selanjutnya item-item pada masing-masing konsep variabel tersebut layak digunakan sebagai alat ukur.

\section{Analisis Kuantitatif}

Persamaan regresi antara variabel Motivasi kerja terhadap Disiplin kerja adalah $\mathrm{Y}=5,554+0,803 \mathrm{X}$, yang artinya setiap kenaikan satu point daripada variabel Motivasi kerja akan diikuti oleh naiknya variabel Disiplin kerja pada Badan Perencanaan Pembangunan Daerah Kabupaten Tulang Bawang Barat sebesar 0,803 point.

Dari hasil penelitian di nyatakan bahwa motivasi Kerja pegawai pada Badan Perencanaan Pembangunan Daerah Kabupaten Tulang Bawang Barat dari hasil uji t didapat nilai $t_{\text {hitung }}=7,145$. Apabila dibandingkan dengan $t_{\text {tabel }}$ pada taraf signifikan 0,05 yaitu 1,682, maka thitung $=$ $7,145>t_{\text {tabel }} 1,682$ kesimpulannya bahwa hipotesa yang menyatakan terdapat pengaruh antara variabel Motivasi kerja (X) 
terhadap Disiplin (Y) pada Badan Perencanaan Pembangunan Daerah Kabupaten Tulang Bawang Barat. Jadi variabel Motivasi kerja (X) berpengaruh terhadap variabel Disiplin (Y) dapat diterima. Kemudian berdasarkan Koefisien Determinasi $(\mathrm{KD}) \mathrm{R}^{2}=0,694^{2}=0,477=$ $0,477 \times 100=47,7 \%$. Dapat disimpulkan bahwa variabel Motivasi kerja menjelaskan variasi perubahan terhadap variabel Disiplin pada Badan Perencanaan Pembangunan Daerah Kabupaten Tulang Bawang Barat sebesar 47,7\%, sedangkan sisanya dijelaskan oleh faktor lain yang tidak dikaji dala penelitian ini. Selanjutnya persamaan regresi antara variabel Motivasi kerja terhadap Disiplin adalah $\mathrm{Y}=5,554+$ $0,803 \mathrm{X}$, yang artinya setiap kenaikan satu point daripada variabel Disiplin kerja akan diikuti oleh naiknya variabel kinerja pada Badan Perencanaan Pembangunan Daerah Kabupaten Tulang Bawang Barat sebesar 0,803 point.

Menurut pendapat dan hemat peneliti, diterimanya hipotesis yang menyatakan terdapat pengaruh antara variabel motivasi (X) terhadap variabel Displin (Y) di Badan Perencanaan Pembangunan Daerah Kabupaten Tulang Bawang Barat, karena dari hasil perhitungan Koefisien Determinasi $(\mathrm{KD})=\mathrm{R}^{2}=0,694^{2}=0,477=$ $0,477 \times 100=47,7 \%$, yang diartikan variabel Motivasi Kerja (X) menjelaskan variasi perubahan terhadap variabel Disiplin (Y) di Badan Perencanaan Pembangunan Daerah Kabupaten Tulang Bawang Barat sebesar 47,7 \%, sedangkan sisanya sebesar 52,3 \% dijelaskan oleh faktor lain yang tidak dikaji dalam penelitian ini. Kemudian dalam persamaan regresi antara variabel Motivasi Kerja (X) terhadap variabel Disiplin (Y) adalah $\mathrm{Y}=$ $5,554+0,803 \mathrm{X}$, yang artinya setiap kenaikan satu point daripada variabel Motivasi kerja akan diikuti oleh naiknya variabel Disiplin pada Badan Perencana Pembangunan Daerah Kabupaten Tulang
Bawang Barat sebesar 0,803 point, karena Disiplin Kerja pegawai di Badan Perencana Pembangunan Daerah Kabupaten Tulang Bawang Barat ini terdukung oleh adanya kesadaran dan kesediaan mentaati semua peraturan organisasi dan norma-norma sosial yang berlaku, Selalu datang dan pulang tepat pada waktunya dan mengerjakan semua pekerjaannya dengan baik.

\section{KESIMPULAN DAN SARAN}

\section{Kesimpulan}

Dari hasil penelitian dan pembahasan maka dapat ditarik kesimpulan bahwa hipotesa yang menyatakan terdapat pengaruh antara variabel Motivasi kerja (X) terhadap Disiplin (Y) pada Badan Perencana Pembangunan Daerah Kabupaten Tulang Bawang Barat. Jadi variabel Motivasi kerja (X) berpengaruh terhadap variabel Disiplin (Y) dapat diterima. Kemudian berdasarkan Koefisien Determinasi $(\mathrm{KD}) \mathrm{R}^{2}=0,694^{2}=0,477=$ $0,477 \times 100=47,7 \%$. Motivasi kerja menjelaskan variasi perubahan terhadap variabel Disiplin pada Badan Perencana Pembangunan Daerah Kabupaten Tulang Bawang Barat sebesar 47,7\%, sedangkan sisanya dijelaskan oleh faktor lain yang tidak dikaji dala penelitian ini. Sedangkan persamaan regresi antara variabel Disiplin kerja terhadap kinerja adalah $\mathrm{Y}=5,554+$ $0,803 \mathrm{X}$, yang artinya setiap kenaikan satu point daripada variabel Motivasi kerja akan diikuti oleh naiknya variabel Disiplin pada Badan Perencana Pembangunan Daerah Kabupaten Tulang Bawang Barat sebesar 0,803 point.

\section{Saran}

Sebagai saran dari hasil penelitian ini yang merupakan bentuk rekomendasi 
untuk penelitian selanjutnya, adalah sebagai berikut :

1. Dalam penelitian ini jawaban responden yang berkenaan motivasi merupakan hal yang melatarbelakangi individu berbuat untuk mencapai tujuan tertentu adalah sebesar 5,294 yang merupakan jawaban terkecil, haruslah diperhatikan oleh lembaga penyelenggaraan Pemerintahan pada Badan Perencana Pembangunan Daerah Kabupaten Tulang Bawang Barat ini karena hal ini merupakan bagian dari motivasi kerja pegawai selaku pelayan masyarakat.

2. Selain itu juga para pegawai pada Badan Perencana Pembangunan Daerah Kabupaten Tulang Bawang Barat, sebaiknya berusaha selalu menjaga dan meningkatkan disiplin Kerja terutama pada aspek kesadaran dan kesediaan mentaati semua peraturan organisasi dan norma-norma sosial yang berlaku, Selalu datang dan pulang tepat pada waktunya dan mengerjakan semua pekerjaannya dengan baik.

\section{DAFTAR PUSTAKA}

Arikunto, Suharsimi. 2002. Prosedur Penulisan. Jakarta: Bina Aksara.

As'ad. 2002. Psikologi Industri. Yogyakarta: Liberty.

Alwi, Syafaruddin. 2001. Paradigma Baru Manajemen Sumber Daya Manusia. Yogyakarta: Amara.

Bernardin, Russel, Gaspersz, Vincent. 2003. Manajemen Kualitas. Jakarta: Gramedia Pustaka Utama.

Cascio WF and EM Awad. 2002. Human Resourches Management. Virgina: An Information System Aproach.
Fathoni. 2006. Pelayanan Manajemen dan Persaingan Usaha. Jakarta: Gramedia Pustaka Utama.

Friedmann . 1992. Empowement: the Politics of Alternative Development. Cambridge Mass: Blackwell Publisher.

Handoko, T. Hani. 2000. Manajemen Personalia dan Manajemen Sumber Daya Manusia. Yogyakarta: BPFE.

Hasibuan, Malayu S.P. 2008. Manajemen Sumber Daya Manusia. Jakarta: Bumi Aksara.

Ma'rifah, Dewi. 2005. Pengaruh Motivasi Kerja dan Budaya Organisasi Terhadap Kinerja Pekerja Sosial pada UPTD Dinas sosial Jatim. Tesis. http/www.damandiri.com.

Prabu, M. AA. Anwar. 2006. Manajemen SDM Perusahaan. Bandung: Remaja Rosda Karya.

Riduan \& Sunarto. 2009. Pengantar Statistika Untuk Penelitian. Bandung: Alfabeta.

Siagian, Sondang. 2002. Organisasi Kepemimpinan \& Prilaku Administrasi, cetakan kedua. Jakarta: PT. Gunung Agung.

Silalahi, Bennet. 2005. Corporate Culture \& Performance Appraisal. Penerbit YP. Al Hambra. Jakarta.

Supardi, Anwar. 2004. Pengukuran Efektifitas Organisasi. Jakarta: LPFE UI.

Syaifuddin, Azwar. 2003. Reliabilitas dan Validitas. Yogyakarta: Pustaka Pelajar. 